\title{
INCREASED OVERTOPPING SECURITY OF DYKES: A POTENTIAL FOR COMPENSATING FUTURE IMPACTS OF CLIMATE CHANGE
}

\author{
Hanz D. Niemeyer ${ }^{1}$, Ralf Kaiser ${ }^{1}$ and Cordula Berkenbrink ${ }^{1}$
}

\begin{abstract}
Anticipated acceleration of sea level rise in combination with expected higher set-up of storm surges will require strengthening of coastal protection structures. Dykes e. g. must then be heightened according to the existing design rules taking only hydrodynamical loads into consideration. Alternatively the development of new design rules taking both hydrodynamical loads and the strength of the available soil for the construction of a dyke might allow the exploration of up to now undetected safety margins. In order to explore these possibilities the German Coastal Engineering Research Council has provided the funds for a research project targeting these aims. First results of this project are presented in this paper on the background of achieved improvements for the determination of design wave run-up on coastal and estuarine sea dykes.
\end{abstract}

Keywords: climate change impacts, sea-level rise, wave overtopping, design of coastal dykes, hydrodynamic loads, soil mechanics, clay

\section{INTRODUCTION}

Accelerating sea-level rise demands for strengthening of coastal protection structures. Recent investigations on dyke overtopping security indicate that the acceptable overtopping rates are higher than up to now assumed. Therefore in countries with lowlands like Germany or the Netherlands ambitious research programs are carried out in order to deepen and increase the knowledge on overtopping security of dykes.

Aim of this paper is to highlight on one hand the effect of recent improvements in dyke design for existing structures as an additional buffer for an accelerating sea-level rise. On the other the paper will show the prospective advantages being achievable by further improvements in respect of an acceptable increased overtopping security for dykes.

\section{RECENT IMPROVEMENTS IN DYKE DESIGN IN LOWER SAXONY, GERMANY}

The determination of design wave run-up for dykes has been taken seriously into consideration after the disastrous storm surge from February 1962 with a death toll of more than 300 people (Lüders and Leis 1964). But the lack of knowledge about local wave climate in the morphologically enormously differentiated coastal areas and estuaries allowed initially only an empirical design oriented at knowledge about occurring wave run-up during former storm surges. In order to provide sufficient security for the hinterland, estimates of design wave run-up have been carried out by anticipating rather high values for long stretches as a whole (Fig. 1).

Since 1976 measurements of flotsam benchmarks were not only used for the identification of wave run-up but also for its extrapolation for design conditions (Niemeyer 1977), (Niemeyer et al. 1995) allowing a more differentiated evaluation of design wave run-up (Fig. 1).

\begin{tabular}{|lll|}
$\begin{array}{l}\text { until the mid }-70^{\text {th }} \\
\text { global estimate for long } \\
\text { stretches of dyke lines }\end{array}$ & $\begin{array}{l}\text { from 1976 - 1995 } \\
\text { extrapolation of measured } \\
\text { wave run-up after storm } \\
\text { surges by using } \\
\text { benchmarks of flotsam }\end{array}$ & $\begin{array}{l}\text { since 1995 } \\
\text { mathematical modeling of design } \\
\text { waves and computation of wave } \\
\text { run-up with high spatial resolution } \\
\rightarrow \text { almost continuous calculation }\end{array}$ \\
\hline
\end{tabular}

Figure 1. Changes in evaluation of design wave run up in Lower Saxony during last forty years.

Since 1997 design wave conditions are determined by applying the third generation full-spectral wave model SWAN (Ris, Holthuijsen and Booij 1995) providing the input for modified wave run-up formulas (e.g. van Gent 1999) under consideration of an accepted overtopping rate of $3 \%$ (Niemeyer

\footnotetext{
${ }^{1}$ Coastal Research Station of the Lower Saxony Water Management, Coastal Defence and Nature Conservation Agency, An der Mühle 5, 26548 Norderney, Germany, Hanz-Dieter.Niemeyer@nlwkn-ny.niedersachsen.de
} 
and Kaiser 2001). Such detailed studies allow a much more differentiated determination of dyke heights than before.

\section{COMPARISON OF STATE OF THE ART METHODS WITH EMPIRICAL DESIGN AND EXTRAPOLATION METHOD}

In order to check the safety of dykes being empirically designed first tests have been carried out at the Lower Saxon North Sea coast with partly surprising results: The heights of the dykes show up to now undisclosed reserves if the design wave run-up is evaluated by state of the art methods as shown here for a stretch of the dyke line constructed in 1979 (Fig. 2). A further buffer is gained by the then overestimated settling of the construction leading to an additional measure of $1.6 \mathrm{~m}$ against future sealevel rise and increasing storminess. The comparison of a design wave run-up with results from the extrapolation method shows a slighter but still significant reduction of about $25 \%$ leading to a now available safety measure of up to $0.6 \mathrm{~m}$ in exposed coastal areas.

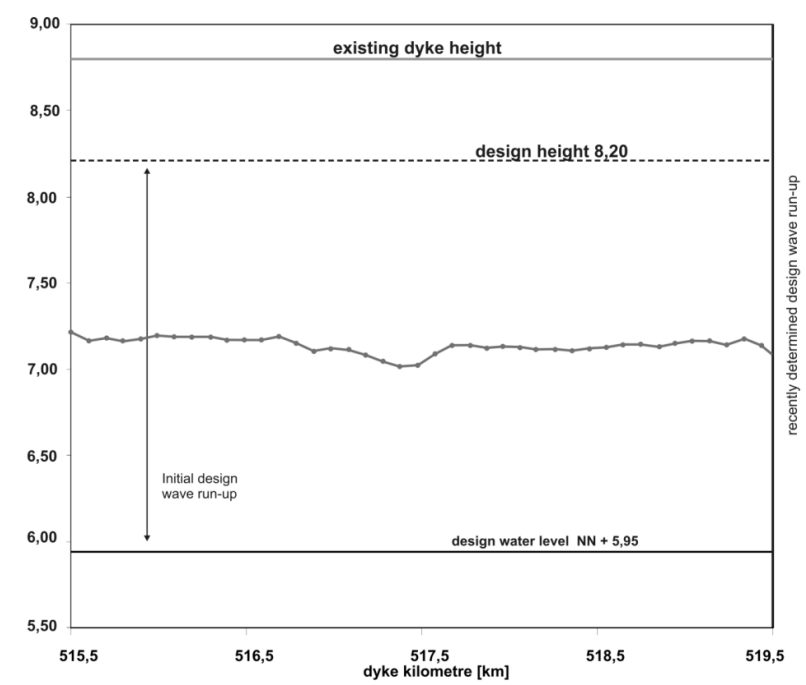

Figure 2. Additional buffer for accelerating sea-level rise due to refined run-up evaluation.

\section{EFFECT OF INCREASING OVERTOPPING SECURITY}

Recent investigations indicated that well built dykes could bear higher overtopping rates than until now anticipated. Particularly prototype tests in the Netherlands documented that a dyke could withstand overtopping rates up to $501 /(\mathrm{m} \mathrm{s}$ ) without damage (Fig. 3).
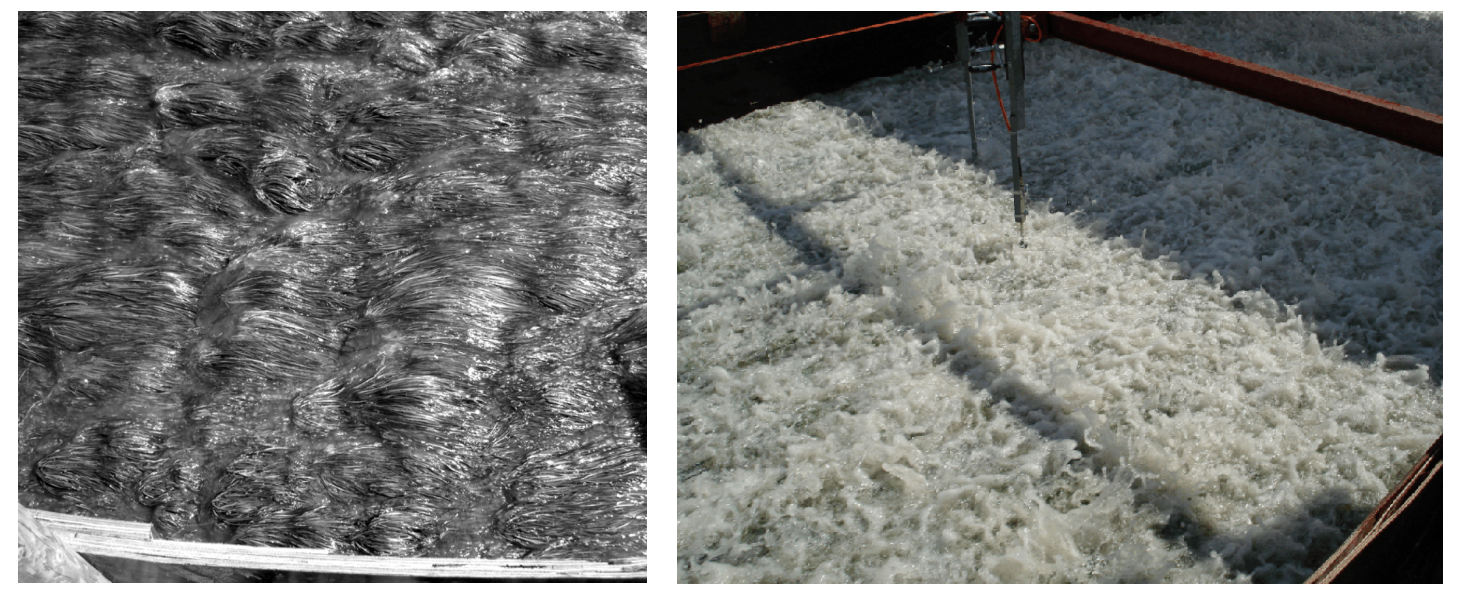

Figure 3. Inner slope of dyke at Delfzijl during overtopping test.

Therefore a joint research project has been started to evaluate acceptable overtopping rates by considering the quality of the clay of the dyke's cover layer. In order to highlight the prospects of this project the effect of increasing overtopping rates on acceptable design water levels has been demonstrated for an exposed coastal dyke (Fig. 4): an increase of more than $50 \mathrm{~cm}$ of the design water 
level would be acceptable for a tolerable overtopping rate of $101 /(\mathrm{min} \bullet \mathrm{s})$ and of nearly $70 \mathrm{~cm}$ for a tolerable overtopping rate of $15 \mathrm{l} /(\mathrm{min} \bullet \mathrm{s})$ which is still remarkably lower than maximum values of the Delfzijl tests.

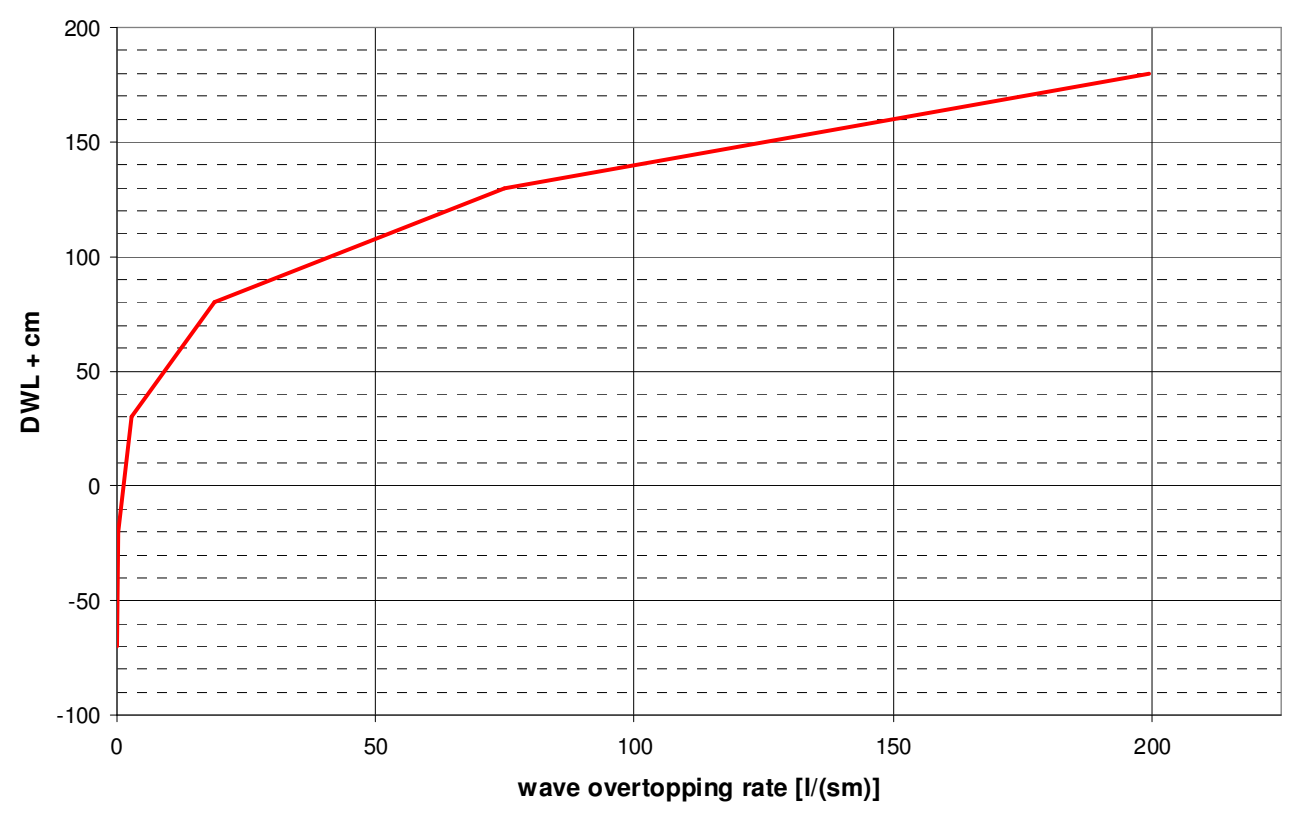

Figure 4. Effect of increasing overtopping security on acceptable design water level (exposed coastal dyke).

Another example is an estuarine dyke with lower attack (Fig. 5): An assumed tolerable overtopping rate of $10 \mathrm{l} /(\mathrm{min} \bullet \mathrm{s})$ would allow an increase of the design water level of more than $50 \mathrm{~cm}$ and of more than $60 \mathrm{~cm}$ for an overtopping rate of $15 \mathrm{l} /(\mathrm{min} \bullet \mathrm{s})$.

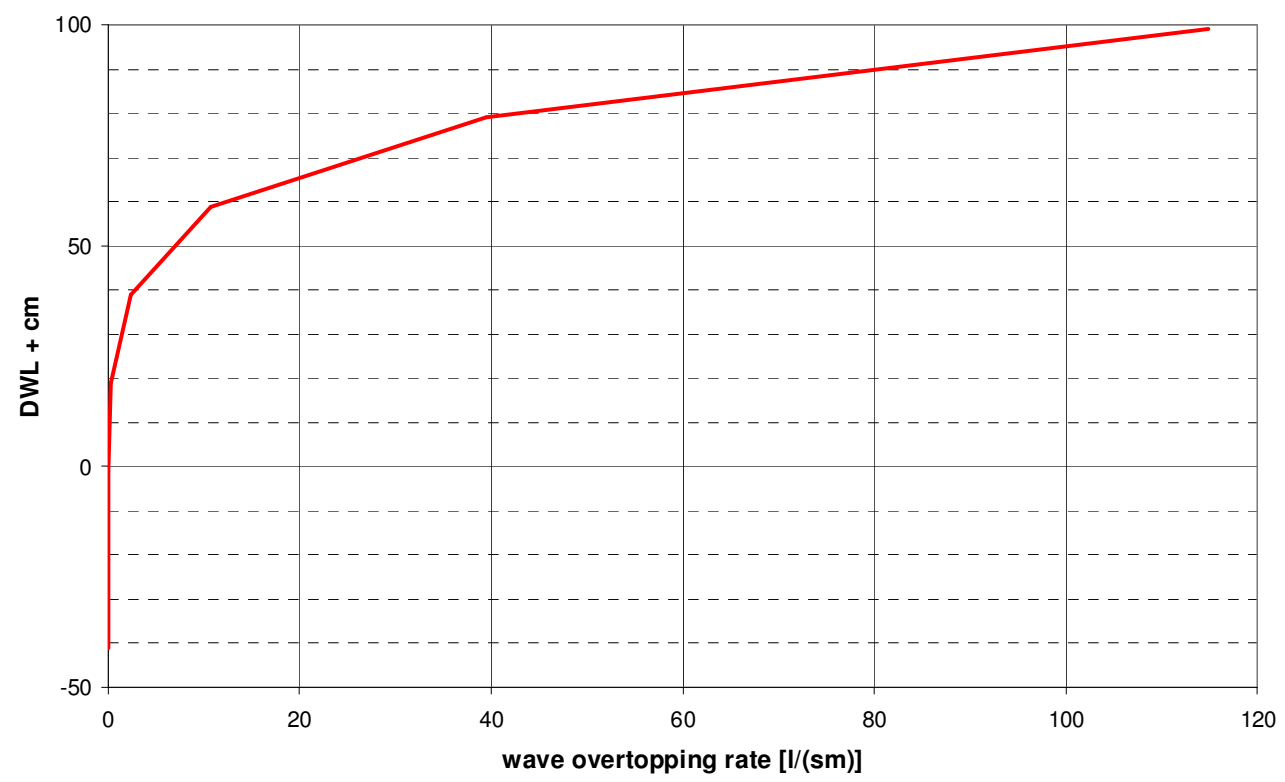

Figure 5. Effect of increasing overtopping security on acceptable design water level (estuarine dyke).

\section{RECENT RESULTS FOR AN INTEGRATED DESIGN APPROACH}

A joint project of Coastal Research Station and the Institute of Soil Mechanics and Foundation Engineering of the Duisburg-Essen University aims at the development of design procedures taking as well hydrodynamical loads as the strength of the clay of dykes quantitatively into consideration. After creating a set-up of design procedures first tests for a dyke at the East Frisian coast in Lower Saxony have been carried out for scenarios of anticipated design water levels ranging from $5.0 \mathrm{~m}$ to $7.5 \mathrm{~m}$ 
above German Datum NN; with steps of $0.5 \mathrm{~m}$. The present design water level is about $5.75 \mathrm{~m}$ above NN. For all these water levels design waves have been modeled by SWAN, exemplarily those for the lowest and highest (Fig. 6). The range of significant wave heights, energy periods and mean wave direction varies correspondingly as follows:

$$
\begin{gathered}
1.76 \mathrm{~m} \leq \mathrm{H}_{\mathrm{m} 0} \leq 2.48 \mathrm{~m} \\
3.6 \mathrm{~s} \leq \mathrm{T}_{\mathrm{m}-1,0} \leq 5.4 \mathrm{~s} \\
310^{\circ} \geq \theta_{\mathrm{m}} \geq 303^{\circ}
\end{gathered}
$$
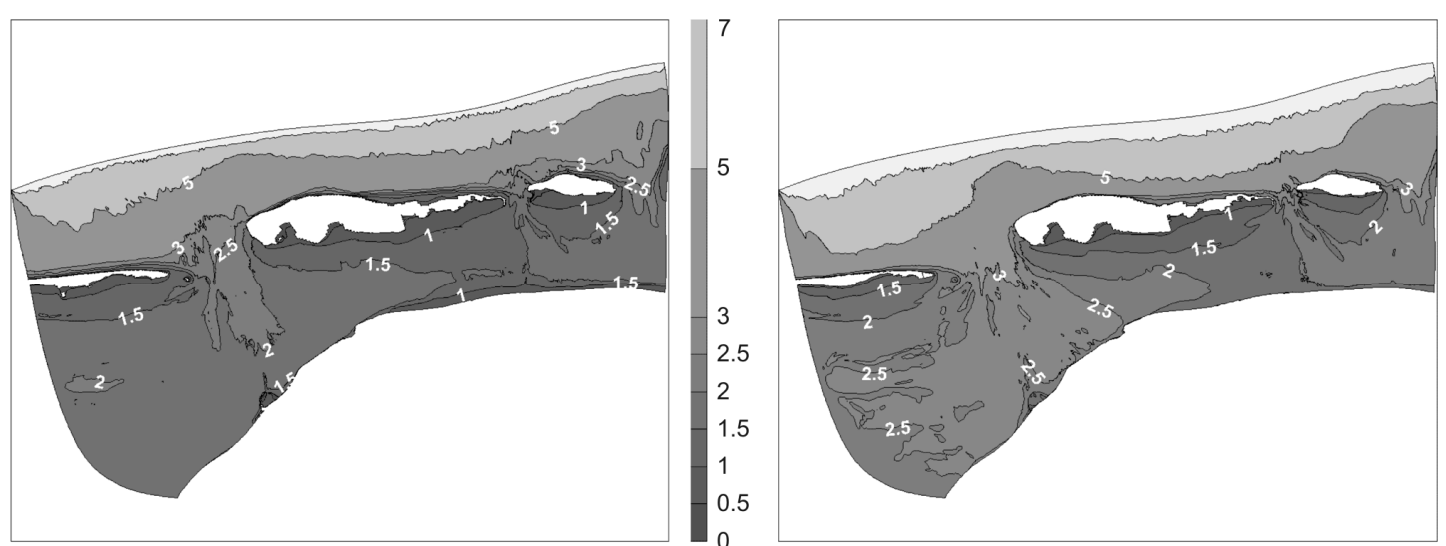

Figure 6. Significant Wave Heights [m] modeled by SWAN (left panel: supposed design water level: 5 m above German datum, right panel anticipated design water level: $7.5 \mathrm{~m}$ above German datum).

The wave spectra at the toe of the dyke at an exposed position for each anticipated design water level are used as boundary conditions for the modeling of wave run-up and overtopping on the dyke is which carried out by the shallow water wave model OTT-1d (Dodd et al. 1998). The dyke has a crest height of about $8.0 \mathrm{~m}$ above $\mathrm{NN}$, an outer slope of 1:6 and an inner one of 1:3. The clay layer has a thickness of $1.5 \mathrm{~m}$ at the outer slope and crest and of $1.0 \mathrm{~m}$ on the inner slope (Fig. 7).

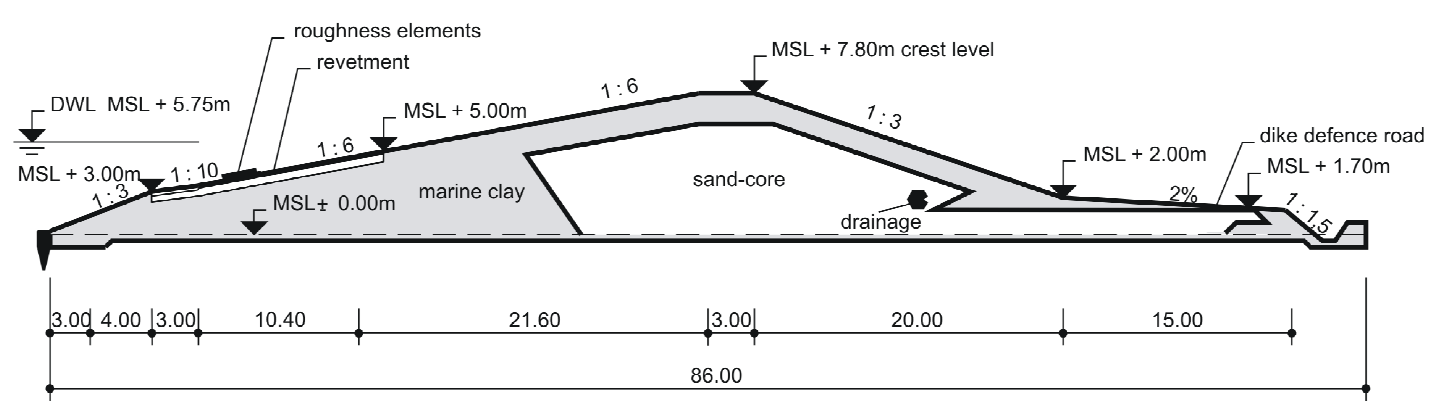

Figure 7. Dyke profile at the East Frisian coast in Lower Saxony.

The mean overtopping rates increase enormously with design water levels and wave parameters (Fig. 8) reaching a maximum of approximately $200 \mathrm{l} /(\mathrm{s} \mathrm{m})$ for a design water level of $\mathrm{NN}+7.5 \mathrm{~m}$. The present design water level leads to low mean overtopping rates. For higher overtopping rates the tolerable design water level could be raise, see the tests in Delfzijl. The dyke was able to bear $501 /(\mathrm{s}$ $\mathrm{m}$ ), that means for this example a tolerable design water level of $\mathrm{NN}+6.7 \mathrm{~m}$. These mean overtopping rates their corresponding layer thicknesses and velocities have been used in order to determine the capability of distinct clay quality. A schematic representation visualizes the design method (Fig. 9). 


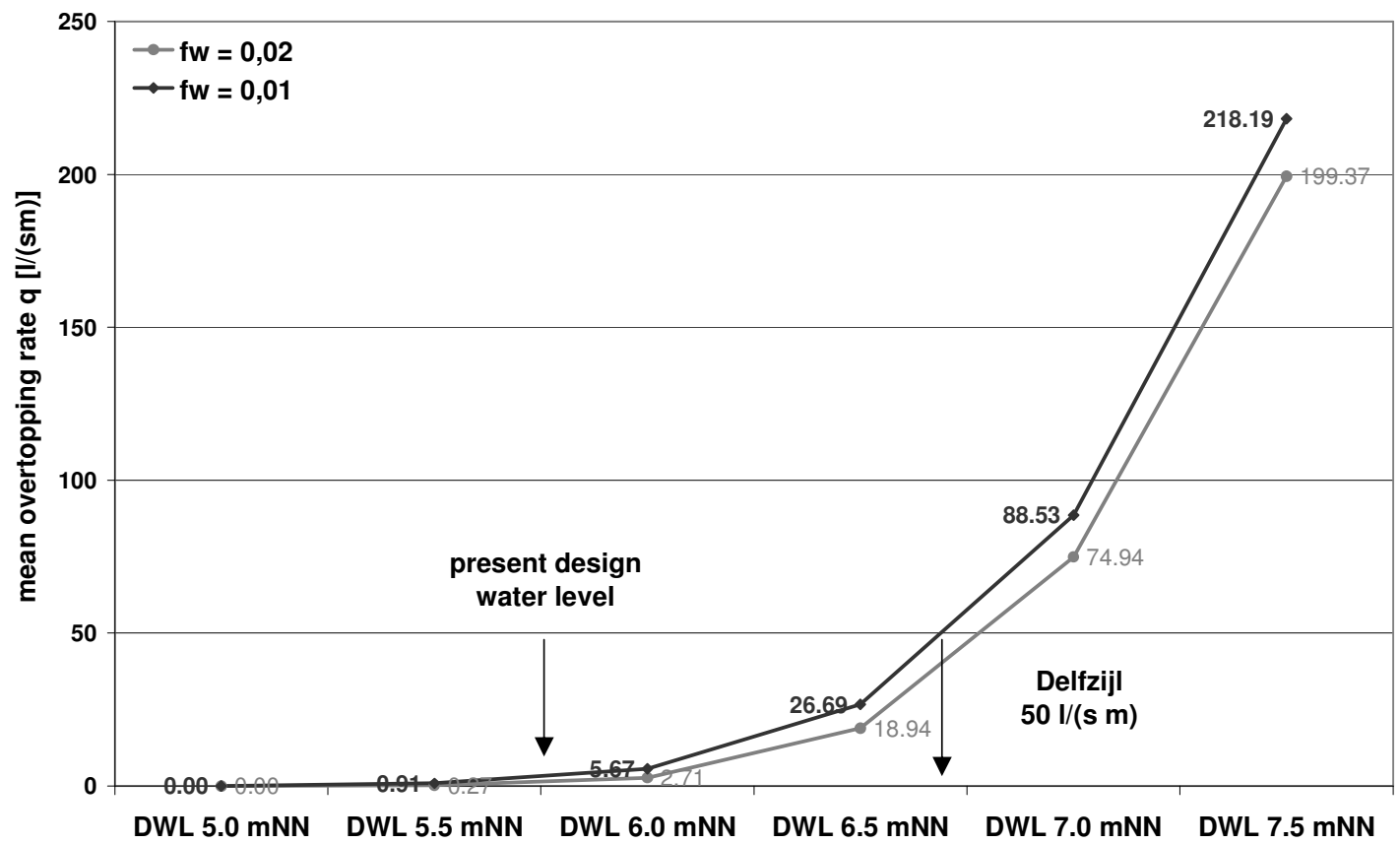

Figure 8. Mean Overtopping rates for different design level scenarios.

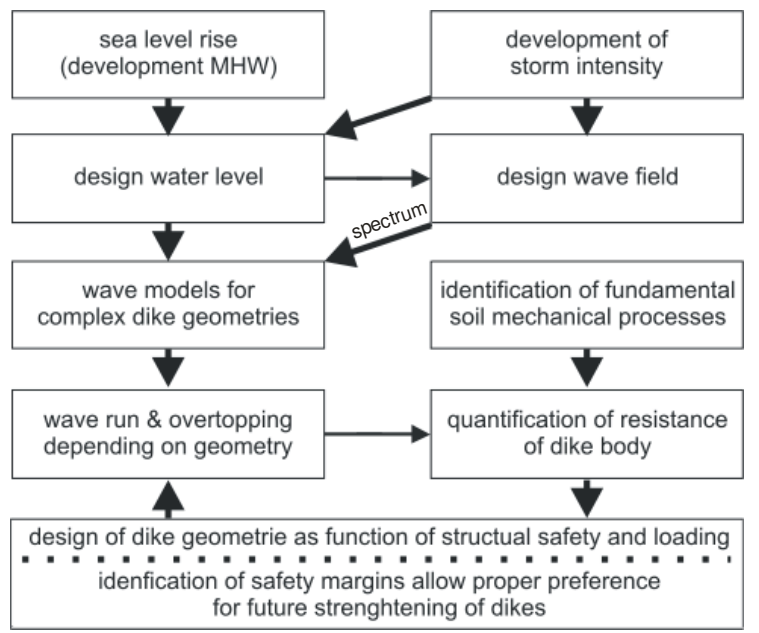

Figure 9. Design method.

\section{SLOPE PARALLEL SLIDING}

The hydrodynamic loads result in soil mechanical processes like erosion and infiltration. Because of this consistency wetting the soil softens and looses its strength. The Inner slope is loaded with overtopping water and in combination with the soil dead weight the flow forces can initiate slope parallel sliding of the cover layer (Fig. 10). The sand-core is defenseless against the following overtopping waves. Normally the slope parallel sliding is signalized by fissures along the dyke crest a bulge at the inner toe (Weißmann 2003). 

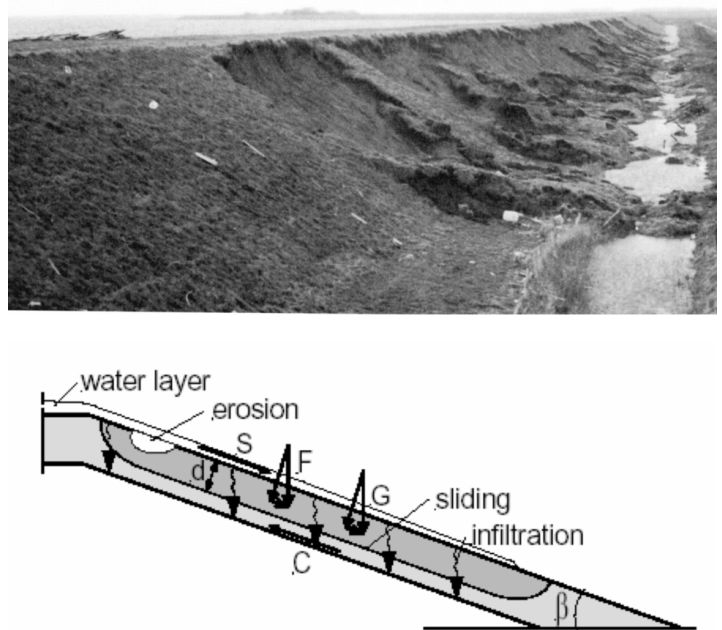

Figure 10. Slope parallel sliding, up (Petersen and Rohde 1991), down (Pohl and Richwien 2008).

With the hydrodynamic loads modeled by OTT-1d the level of utilization for slope parallel sliding is calculated for different types of soil. They are categorized by Weißmann (2003) from "less qualified" (Elisabethgroden 3.5) over "well qualified" (Elisabethgroden 9.0, Wustrow) up to "very well qualified" (Cäciliengroden I, II, Hohenkirchen (Fig. 11). Every type except "Wustrow" is clay. "Wustrow" is a marly soil. The safety against slope parallel sliding is given by the level of utilization $\alpha_{\mathrm{s}}<1$.

The "less qualified" soil is above that level whereas the higher qualified soils do not. The resistance of the soil increases furthermore with the grade of compression (Fig. 12). The higher the grade of compression, the lower the level of utilization because there are less cavities and less water.

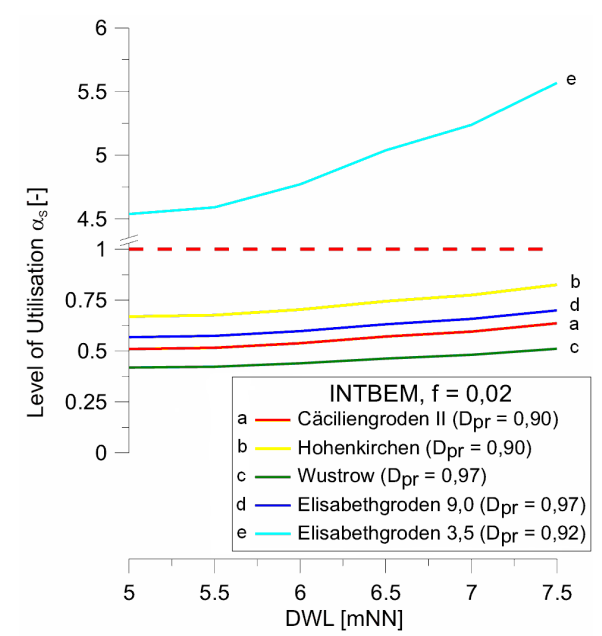

Figure 11. Safety against slope parallel sliding for different types of soil (Pohl and Richwien 2008).

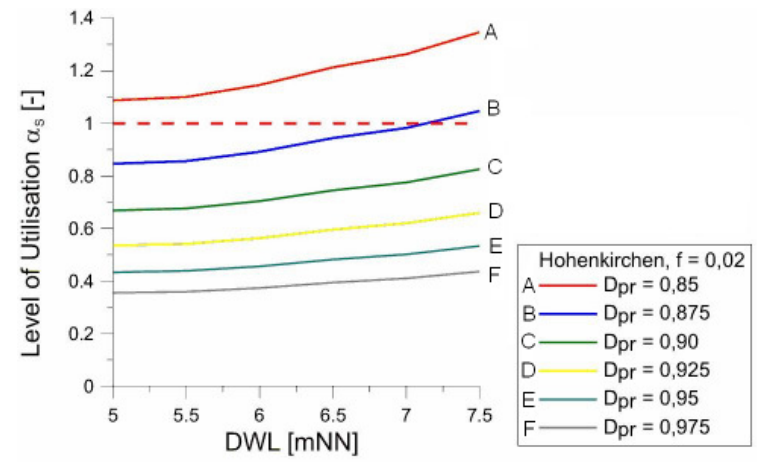

Figure 12. Safety against slope parallel sliding for different grades of compression (Pohl and Richwien 2008).

\section{CONCLUSIONS AND OUTLOOK}

There is an enormous potential of additional safety for sea and estuarine dykes with respect to acceptable overtopping rates. The currently applied design procedures with its very conservative low overtopping tolerances require higher dykes than necessary. The first examples of recent research will be intensified in the next future in order to establish afterwards new design procedures by use of these results for a cost-saving countermeasure against future accelerating sea-level rise.

\section{ACKNOWLEDGMENTS}

The investigations were carried out jointly by Coastal Research Station of the Lower Saxony Water Management, Coastal Defence and Nature Conservation Agency and the Institute for Soil Mechanics and Foundation Engineering at Duisburg-Essen University. The authors are grateful for the fruitful 
collaboration with Professor Werner Richwien and his coworkers Carsten Pohl and Lars Vavrina, who delt with soil mechanics.

The research was funded by the German Federal Ministry for Education and Research under the umbrella of the German Committee on Coastal Engineering Research (project code 03KIS062) and supported by the Lower Saxon Ministry for Environment and Climate Protection.

\section{REFERENCES}

Dodd, N., Giarrusso, C. C. and Nakamura, S., 1998. Anemone: OTT-1d - A User Manual, Report TR 50, HR Wallingford

Lüders, K. and Leis, G., 1964. Niedersächsisches Deichgesetz - Kommentar. Verl. Wasser u. Boden, Hamburg

Niemeyer, H. D., 1977. The Estimation of Design Wave Run-up on Sea Dykes in Consideration of Overtopping Security. Proc. 17th IAHR- Congress, Baden-Baden

Niemeyer, H. D., Gärtner, J., Kaiser, R., Peters, K. H. and Schneider, O., 1995. Estimation of Design Wave Run-up on Sea Dykes under Consideration of Overtopping Security by Using Benchmarks of Flotsam. Proc. 4th Conf. Coast. \& Port Eng. i. Develop. Countr., Rio de Janairo/Brazil

Niemeyer, H. D. and Kaiser, R., 2001. Design Wave Evaluation for Coastal Protection Structures in the Wadden Sea. Proc. 4th Int. Symp. Ocean Wave Meas. \& Analysis 2001. San Francisco. ASCE, Reston/Va., USA

Petersen, M. and Rohde, H., 1991. Sturmflut. Die großen Fluten an den Küsten Schleswig-Holsteins und in der Elbe, Karl Wachholtz Verlag, 3. Verb. Auflage, Neumünster

Pohl, C. and Richwien, W., 2008. INTBEM: Bewertung der Standsicherheit von Seedeichbinnenböschungen bei Wellenüberlauf - Statische Sicherheit gegen hangparalleles Gleiten. Bericht an den Förderer (unveröff.)

Ris, R., Holthuijsen, L. H., and Booij, N., 1995. A Spectral Model for Water Waves in the Nearshore Zone. Proc. 24th int. Conf. Coast. Eng. Kobe/Japan. ASCE, New York

Van Gent, M., 1999. Wave run-up and Overtopping for Double Peaked Wave Energy Spectra. WLIDelft Hydraulics, Rapp. H 3551

Weißmann, R., 2003. Die Widerstandsfähigkeit von Seedeichbinnenböschungen gegenüber ablaufendem Wasser, Universität Duisburg-Essen, Mitteilungen aus dem Fachgebiet für Grundbau und Bodenmechanik, Heft 30, Glückauf Verlag, Essen 